\title{
Carpe diem
}

Avril 2001

En avril, « ne te découvre pas d'un fil », mais profite du jour présent pour cueillir, sur les images offertes par le satellite, les phénomènes inhabituels, inattendus ou spectaculaires ! Ainsi, trois journées consécutives nous permettent d'observer banquise, pack et perturbation le long de la côte sud-est du Groenland (en haut), une réflexion spéculaire très originale (au centre) et trois lignes de grains africaines qui pénètrent sur l'océan (en bas).

Patrick Donguy et Daniel Pochic
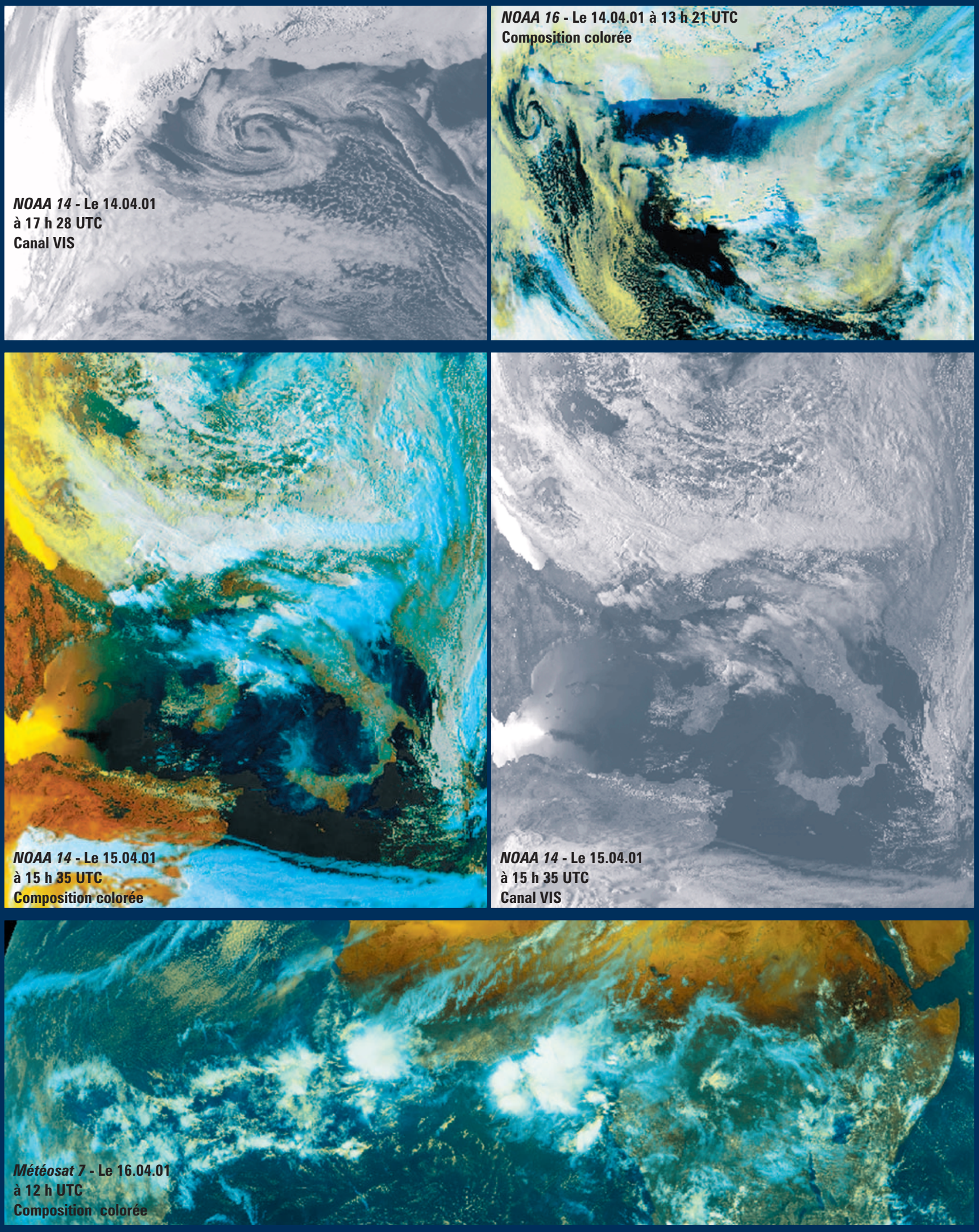

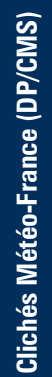

